Supporting Information

\title{
Speedy, Specific, Synchronous Sensing Platforms with Ruthenium Complexes for Multiplexed MicroRNAs Detection
}

Rong-Tian Li, ${ }^{\dagger}$ Zhen Liang, ${ }^{\dagger}$ Meng-Chu Li, ${ }^{\dagger}$ Yong Tan, ${ }^{\dagger}$ Bao-Ping Xie, ${ }^{\dagger}$ Wen-Jun Duan,${ }^{\dagger}$ Chun-Tao Ning, ${ }^{\dagger}$ Jin-Xiang Chen, ${ }^{*}, \dagger$ and Bin Sun $*, \dagger$

${ }^{\dagger}$ Guangdong Provincial Key Laboratory of New Drug Screening and Guangzhou Key Laboratory of Drug Research for Emerging Virus Prevention and Treatment, School of Pharmaceutical Sciences, Southern Medical University, Guangzhou 510515, China

* Department of Pharmacy, Zhujiang Hospital, Southern Medical University, Guangzhou 510282, China

E-mail: jxchen@smu.edu.cn, sunbb@,smu.edu.cn 
Figure S1. ESI-MS (a), ${ }^{1} \mathrm{H}$ NMR (b) spectra of ligand Dpphz................................ 4

Figure S2. ESI-MS (a), ${ }^{1} \mathrm{H}$ NMR (b), ${ }^{13} \mathrm{C}$ NMR (c) and IR (d) spectra of Ru 2.......... 6

Figure S3. ESI-MS (a), ${ }^{1} \mathrm{H}$ NMR (b), ${ }^{13} \mathrm{C}$ NMR (c) and IR (d) spectra of Ru 3.......... 8

Figure S4. (a) UV/Vis spectra of $\mathbf{R u} \mathbf{1}, \mathbf{R u} 2$ and $\mathbf{R u} 3$ measured in $\mathrm{CH}_{3} \mathrm{CN}$ or Tris- $\mathrm{HCl}$ buffer, (b) Emission spectra of Ru 1, Ru 2 and $\mathbf{R u} 3$ measured in $\mathrm{CH}_{3} \mathrm{CN}$ or

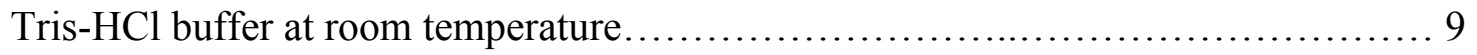

Figure S5. Fluorescence spectra of P-DNA-1 (a) and P-DNA-2 (b) incubated with $\mathrm{T}_{1}$ or $\mathrm{T}_{2}$ of varying concentrations in Tris- $\mathrm{HCl}$ buffer at room temperature............... 9 Figure S6. Fluorescence spectra of P-DNA-1/P-DNA-2 incubated with Ru 1 of varying concentrations at room temperature. 9

Figure S7. Fluorescence intensity of the P-DNA-1@Ru 1 system and P-DNA-2@Ru 1 system in the presence of target $T_{1}$ or $T_{2}$ at varying incubation time 10

Figure S8. Fluorescence spectra of the P-DNA-1@Ru 1 system and P-DNA-2@Ru 1 system incubated with $T_{1}$ or $T_{2}$ of varying concentrations at room temperature. 10 Figure S9. Fluorescence quenching efficiency $\left(\mathrm{Q}_{\mathrm{E}}\right)$ of the P-DNA-1/P-DNA-2 by Ru 2, $\mathrm{RuCl}_{3}$, bpy, Dpphz and the P-DNA-1/P-DNA-2 by $\mathbf{R u} \mathbf{3}, \mathrm{RuCl}_{3}$, dabpy, amtp of varying concentrations 11

Figure S10. Fluorescence spectra of the P-DNA-1@Ru 2, P-DNA-1@Ru 3, P-DNA-2@Ru 2 and P-DNA-2@Ru 3 incubated with $\mathrm{T}_{1}$ or $\mathrm{T}_{2}$ of varying concentrations after different times $(12 \mathrm{~h} / 24 \mathrm{~h})$ at room temperature.

Figure S11. Sensing selectivity and specificity experiments: the fluorescence spectra of P-DNAs@Ru 2/Ru 3 with $\mathrm{T}_{1}$ and $\mathrm{T}_{2}, \mathrm{~T}_{1}, \mathrm{~T}_{2}$ 12

Figure S12. The Stern-Volmer plots for the fluorescence quenching of P-DNA-1/P-DNA-2 to Ru 1, Ru 2 and Ru 3 at different temperatures................ 13

Figure S13. Semilog plots of fluorescence decay versus time of P-DNA-1 (a) and P-DNA-2 (b) dispersed in Tris-HCl solution with the equilibrium concentration of

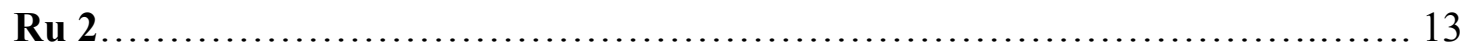

Figure S14. Fluorescence anisotropy changes of P-DNA-1 (P-1) or P-DNA-2 (P-2), $\mathrm{P}-1 @ \mathrm{~T}_{1}$ or P-2@ $\mathrm{T}_{2}$ before and after the addition of Ru (II) complexes. 14

Figure S15. The concentration gradient experiments of PAGE of different concentrations of the Ru 2 against the P-DNA-1/P-DNA-2 ..................... 15

Figure S16. PAGE pattern of the P-DNA-2, $\mathrm{T}_{2}$ and their binding mixtures with the

Ru 2. 15 
Figure S17. Cell viability of MDA-MB-231 (a) and MCF10A (b) cells in vitro treatment with Ru 1, Ru 2, Ru 3 and Cisplatin............................... 15 Figure S18. The single point energies difference $(\Delta \Delta G)$ of $\Delta G_{\text {P-DNA@Ru with }}$

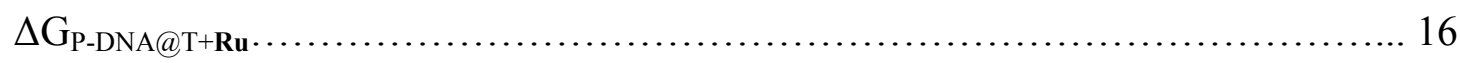

Table S1-7. The single point energy results of P-DNA, P-DNA@T, P-DNA@Ru and P-DNA@T+Ru and the difference $(\Delta \Delta \mathrm{G})$ of $\Delta \mathrm{G}_{\mathrm{P}-\mathrm{DNA} @ \mathbf{R u}}$ with $\Delta \mathrm{G}_{\mathrm{P}-\mathrm{DNA} @ \mathrm{~T}+\mathbf{R u} . \cdots \cdots \cdots . . . .18} 18$ Table S8-S9. The detection efficiency and selectivity data for P-DNA+Ru or P-DNA@Ru systems by single/synchronous fluorescence analysis.......................... 18 Table S10. The $K_{D}$ values of P-DNA-1/P-DNA-2 toward Ru 1, Ru 2 and Ru 3 at

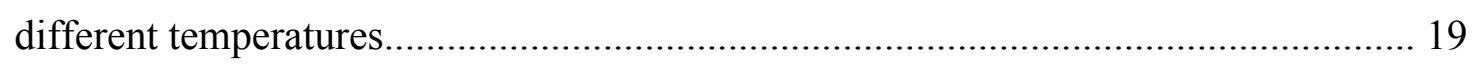

Table S11. The $K_{a}$ values and $n$ values of single stranded P-DNA-1/P-DNA-2 and duplex P-DNA-1/P-DNA-2@T with Ru 1, Ru 2 and Ru 3 at room temperature........ 19 
(a) $2.754(0.818)$

Scan ES+
$8.53 \mathrm{e}^{7}$

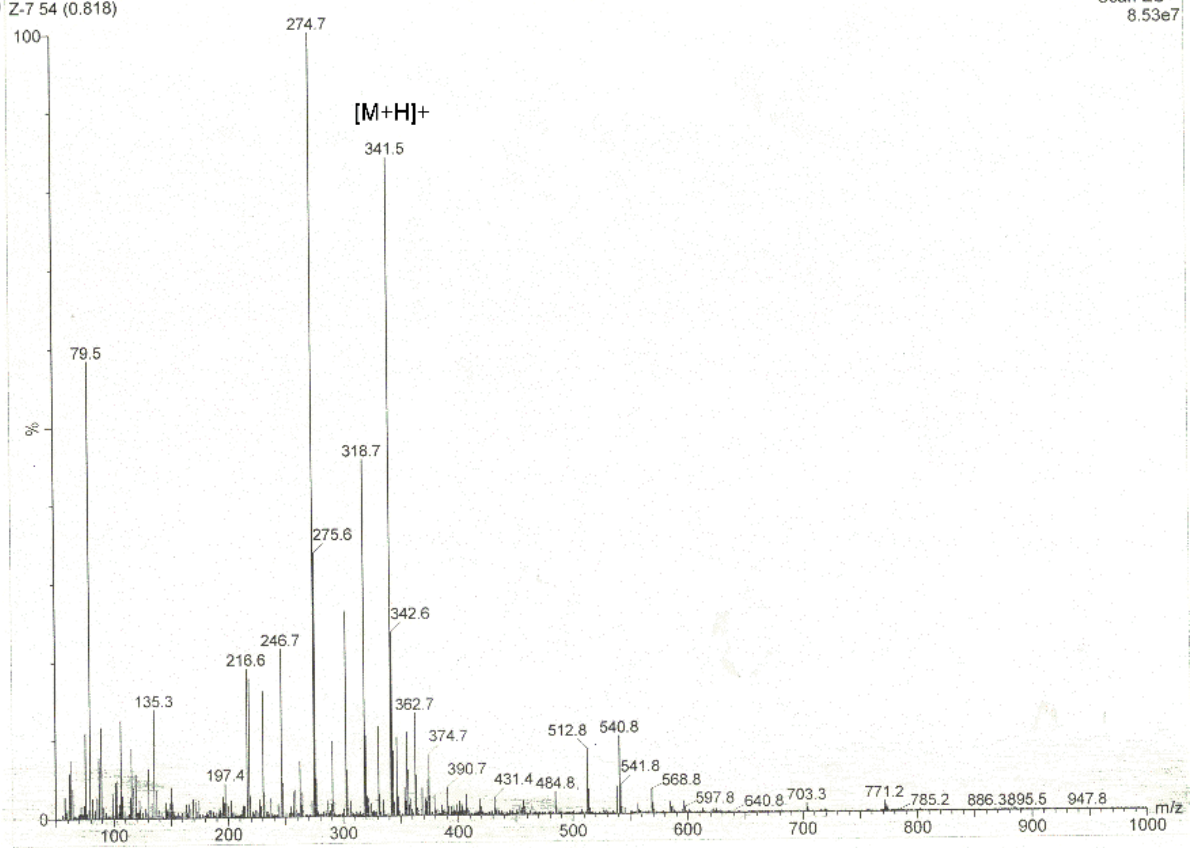

(b)

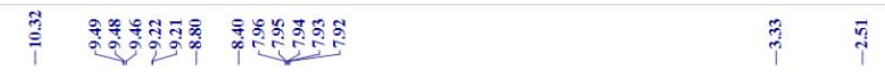

(n)
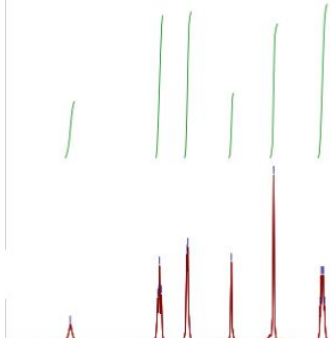

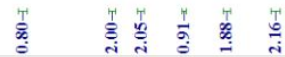

$\begin{array}{llllllllllllllllllllllllll}10.5 & 10.0 & 9.5 & 9.0 & 8.5 & 8.0 & 7.5 & 7.0 & 6.5 & 6.0 & \begin{array}{c}5.5 \\ \mathrm{fl}(\mathrm{ppm})\end{array} & 4.5 & 4.0 & 3.5 & 3.0 & 2.5 & 2.0 & 1.5 & 1.0 & 0.5 & 0.0\end{array}$

Figure S1. ESI-MS (a), ${ }^{1} \mathrm{H}$ NMR (b) spectra of ligand Dpphz. 
(a)

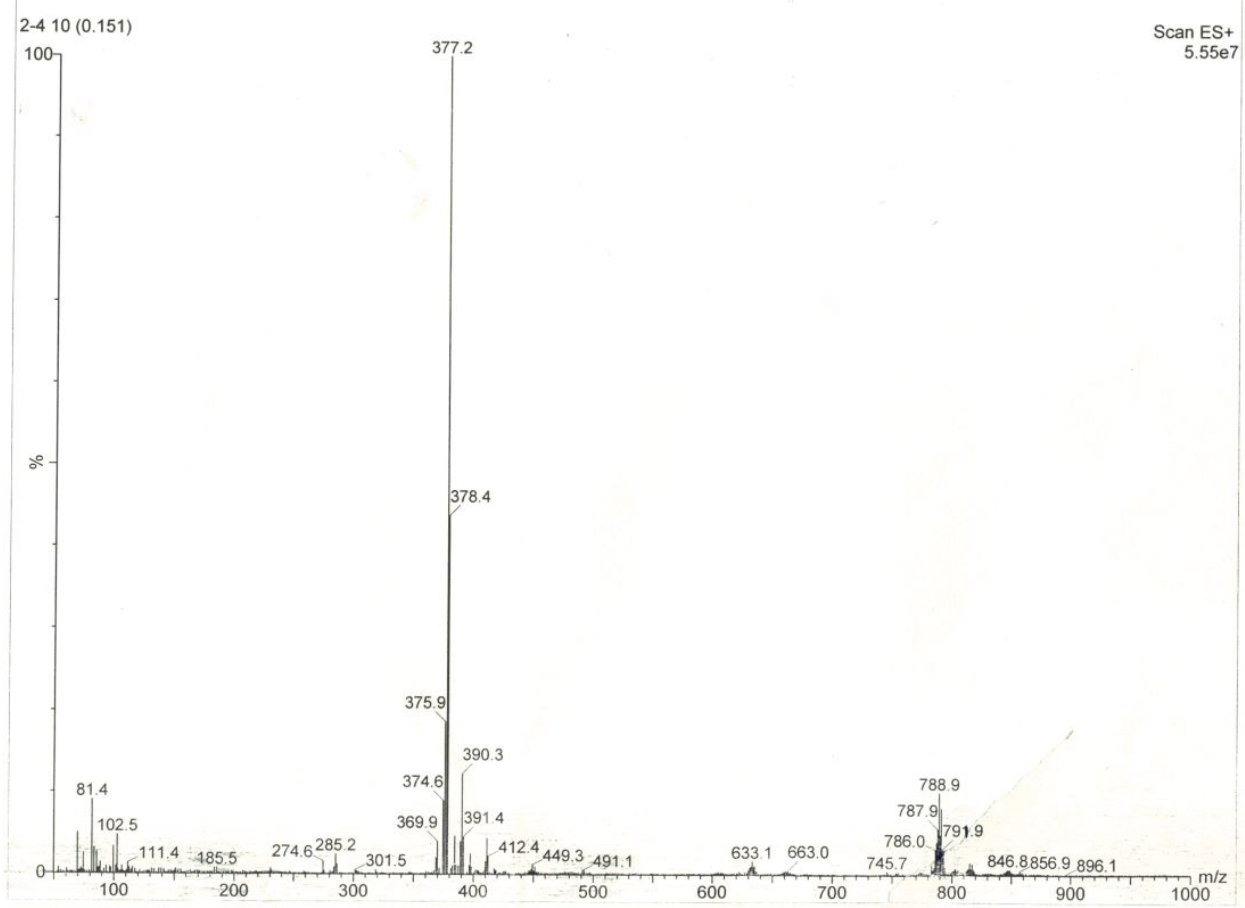

(b)
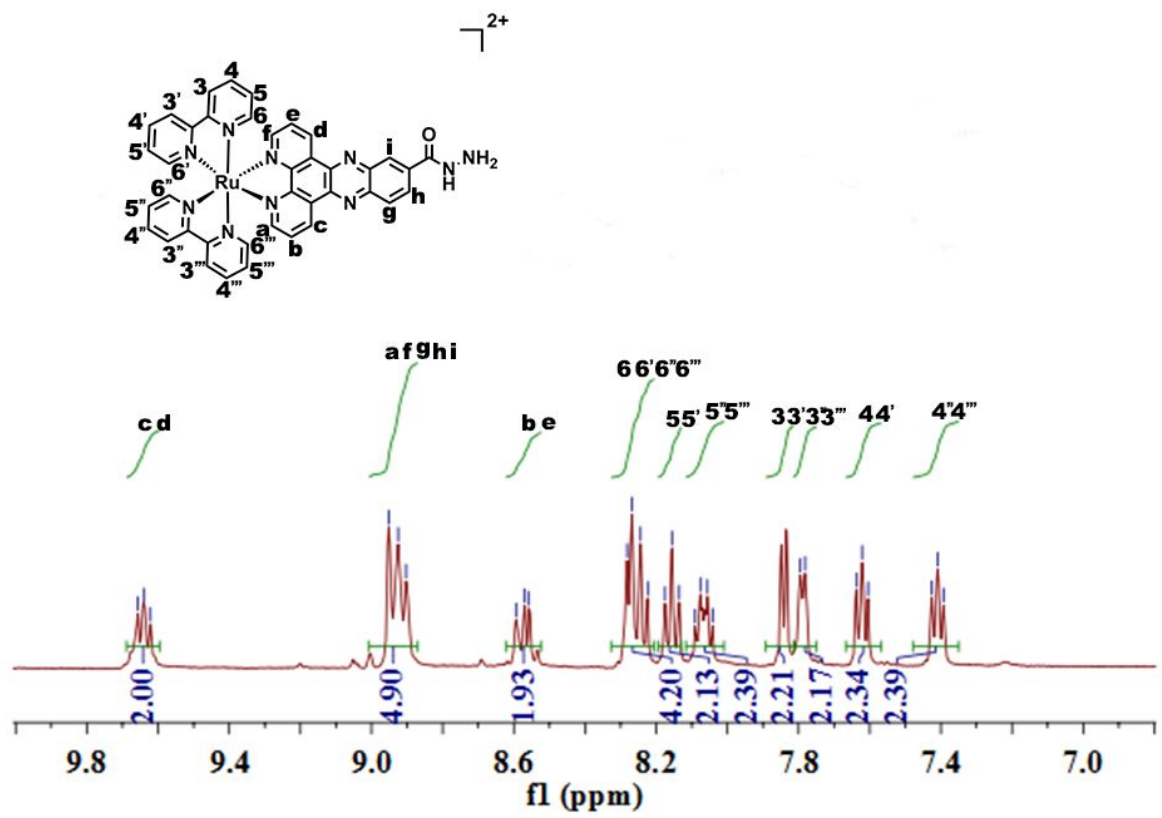
(c)

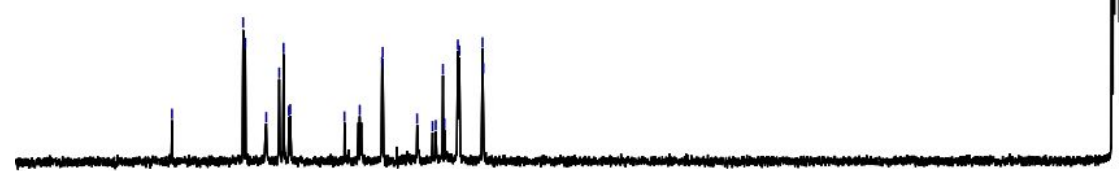

$\begin{array}{lllllllllllllllllllllllll}180 & 170 & 160 & 150 & 140 & 130 & 120 & 110 & \begin{array}{c}100 \\ \mathrm{f} 1(\mathrm{ppm})\end{array} & 80 & 70 & 60 & 50 & 40 & 30 & 20 & 10 & 0\end{array}$

(d)

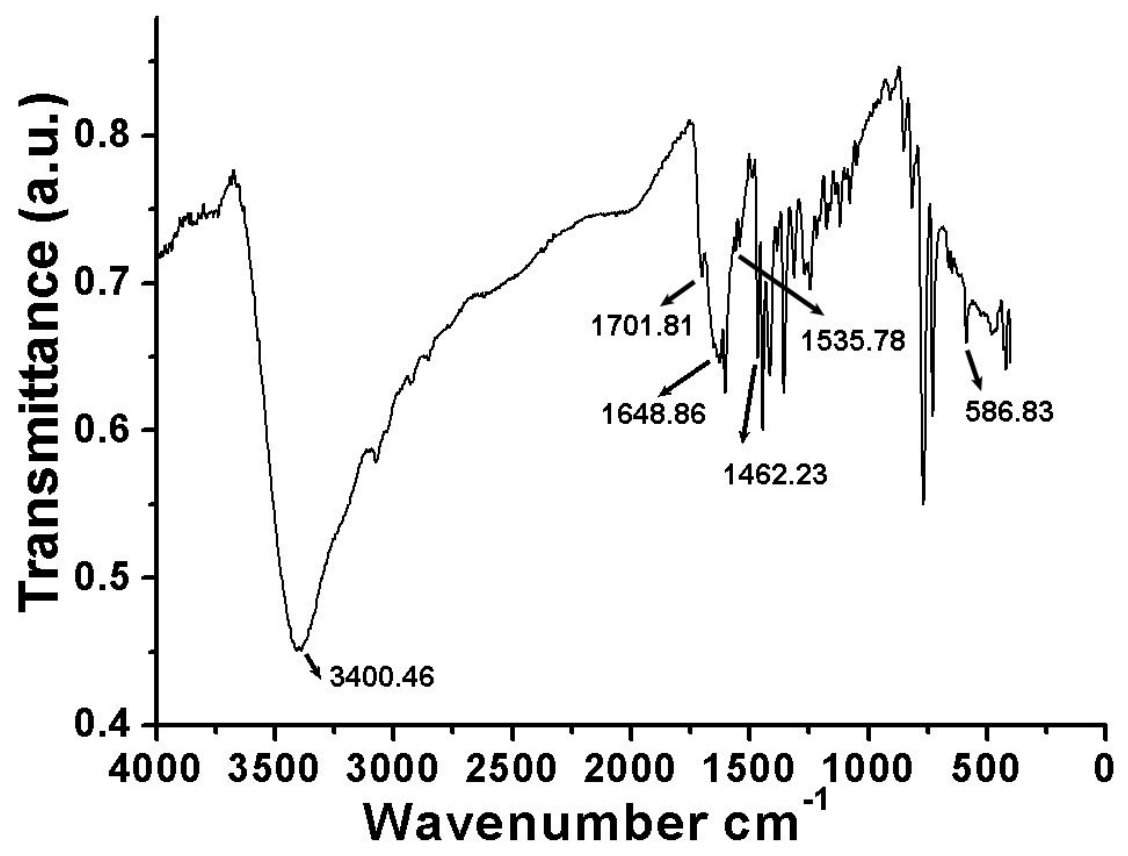

Figure S2. ESI-MS (a), ${ }^{1} \mathrm{H}$ NMR (b), ${ }^{13} \mathrm{C}$ NMR (c) and IR (d) spectra of complex Ru 2 

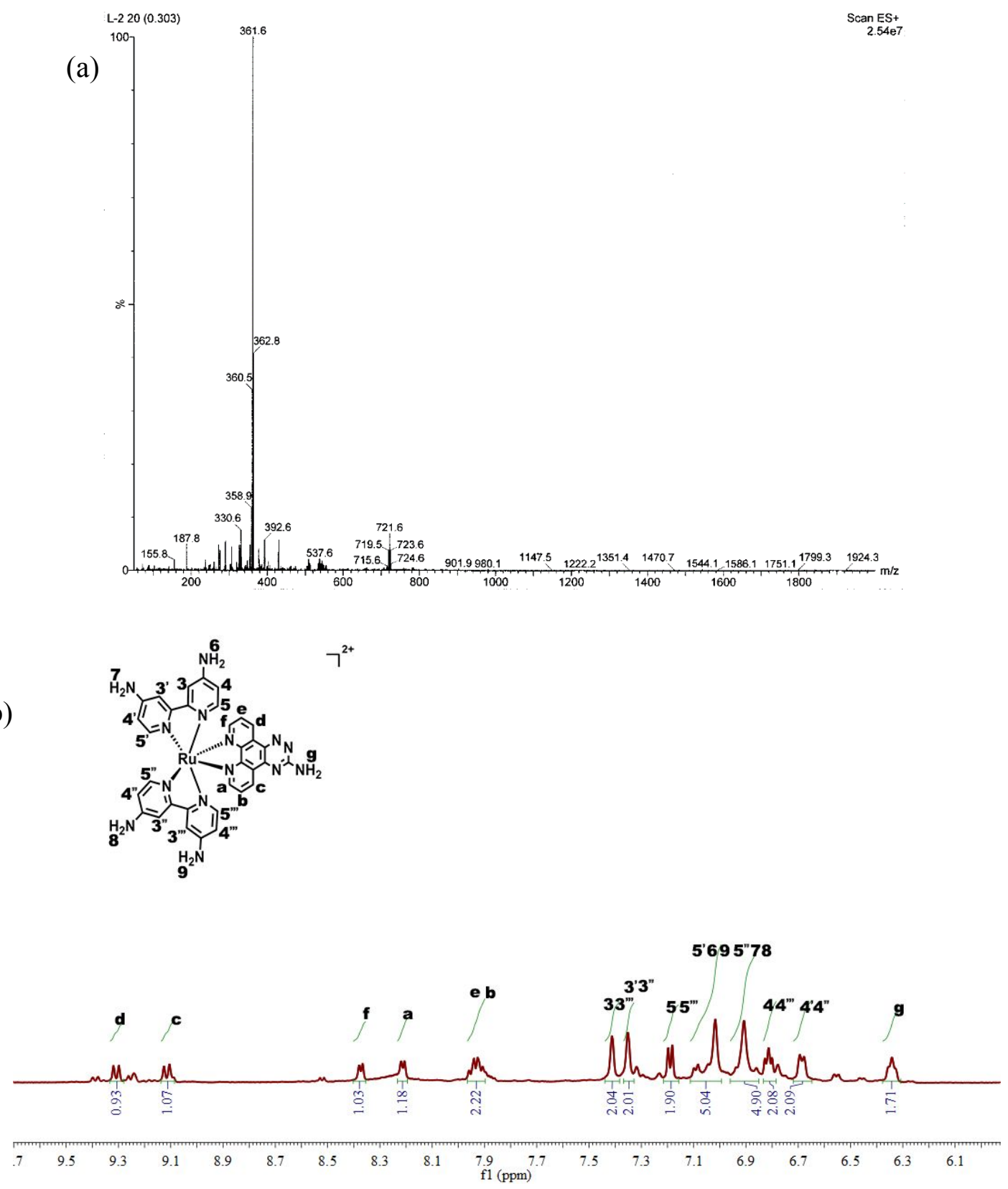
(c) 둥ำ

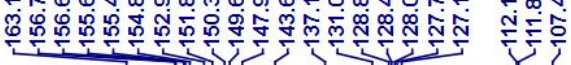

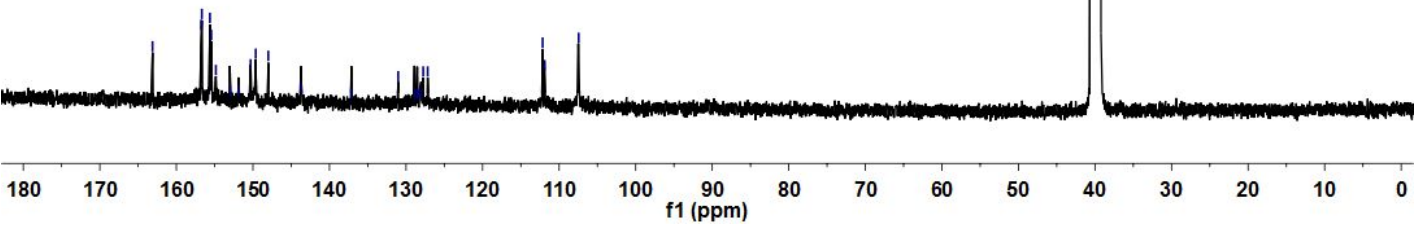

(d)

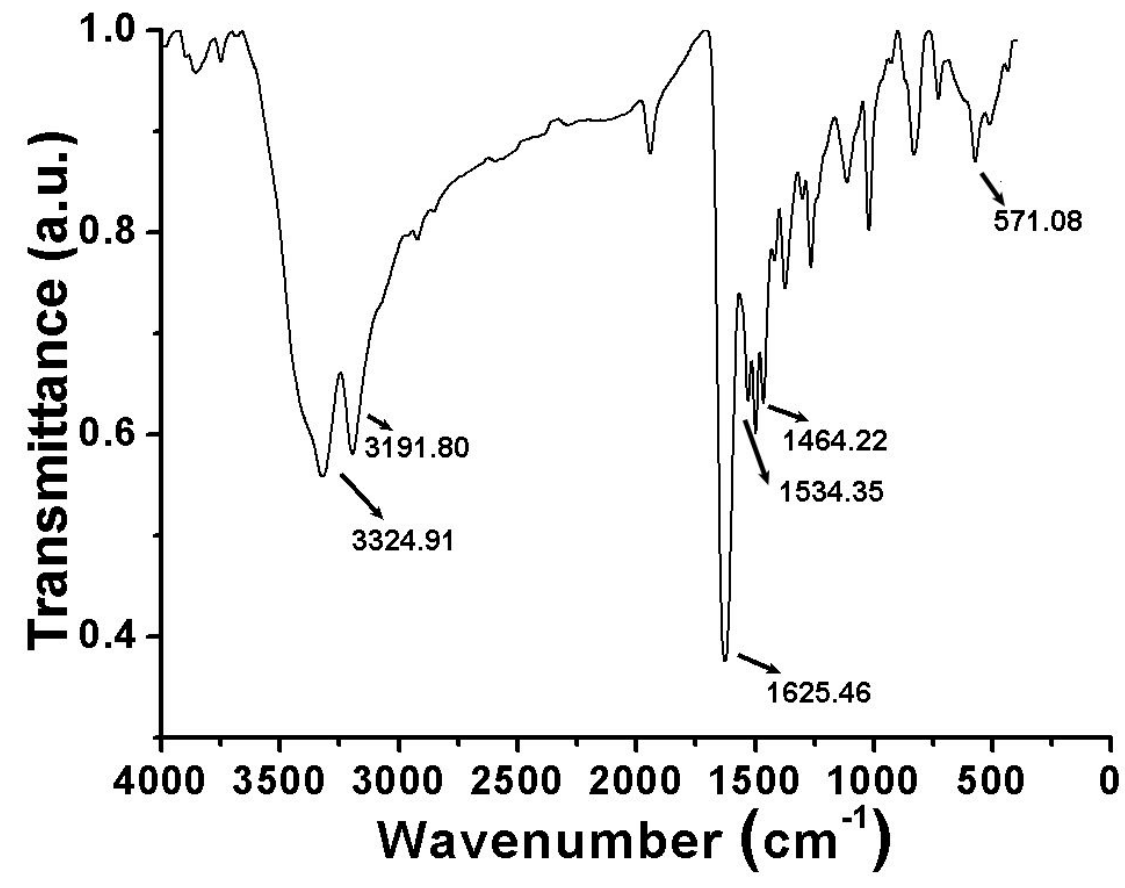

Figure S3. ESI-MS (a), ${ }^{1} \mathrm{H}$ NMR (b), ${ }^{13} \mathrm{C}$ NMR (c) and IR (d) spectra of complex Ru 3 
(a)

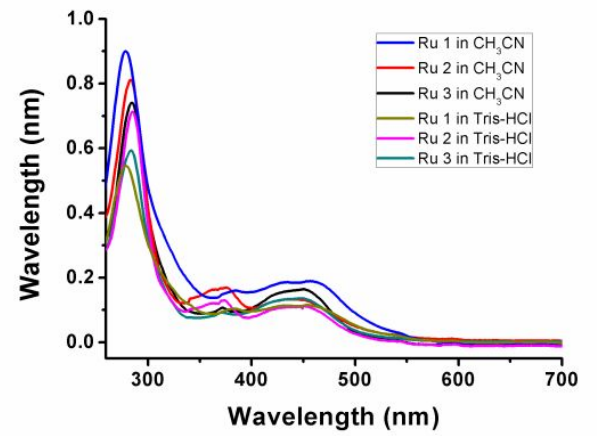

(b)

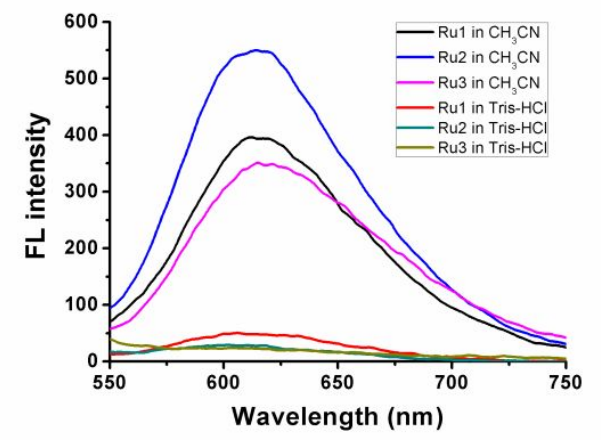

Figure S4. (a) UV/Vis spectra of Ru 1, Ru 2 and $\mathbf{R u} 3(20 \mu \mathrm{M})$ measured in $\mathrm{CH}_{3} \mathrm{CN}$ or Tris-HCl buffer (pH 7.4) at 298 K, (b) Emission spectra of Ru 1, Ru 2 and Ru $3(20 \mu \mathrm{M})$ measured in $\mathrm{CH}_{3} \mathrm{CN}$ or Tris- $\mathrm{HCl}$ buffer $(\mathrm{pH} 7.4)$ at room temperature $\left(\lambda_{\mathrm{ex}}=455 \mathrm{~nm}\right)$.

(a)

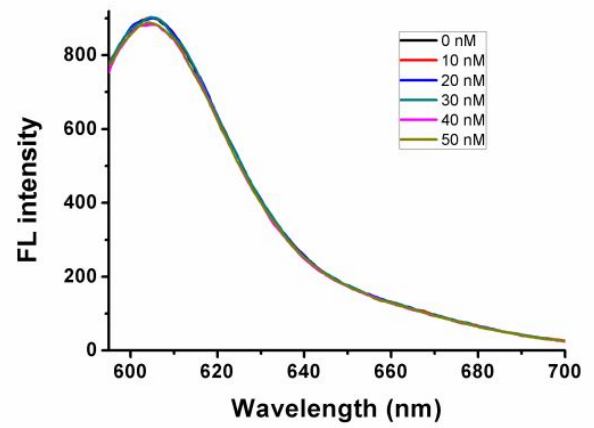

(b)

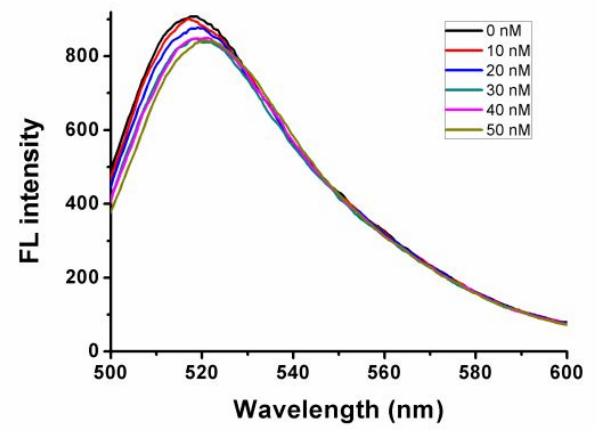

Figure S5. Fluorescence spectra of P-DNA-1 $(50 \mathrm{nM})$ incubated with $\mathrm{T}_{1}$ (a) and P-DNA-2 $(50 \mathrm{nM})$ incubated with $\mathrm{T}_{2}$ (b) of varying concentrations in $100 \mu \mathrm{M}$ Tris- $\mathrm{HCl}$ buffer $(\mathrm{pH} 7.4)$ at room temperature.

(a)

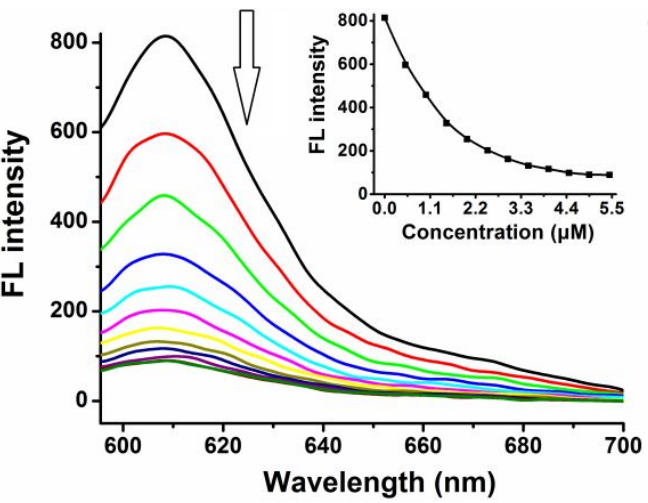

(b)

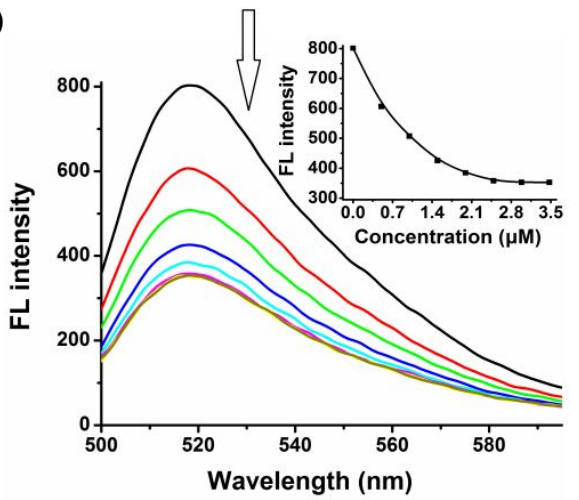

Figure S6. Fluorescence spectra of P-DNA-1 (a) and P-DNA-2 (b) incubated with Ru 1 of varying concentrations at room temperature. Insets: plots of fluorescence intensity at $608 \mathrm{~nm}$ and $518 \mathrm{~nm}$ versus the concentrations of Ru 1. 
(a)

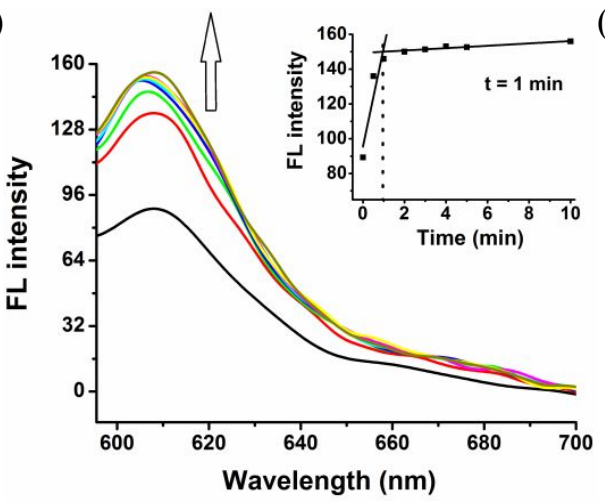

(b)

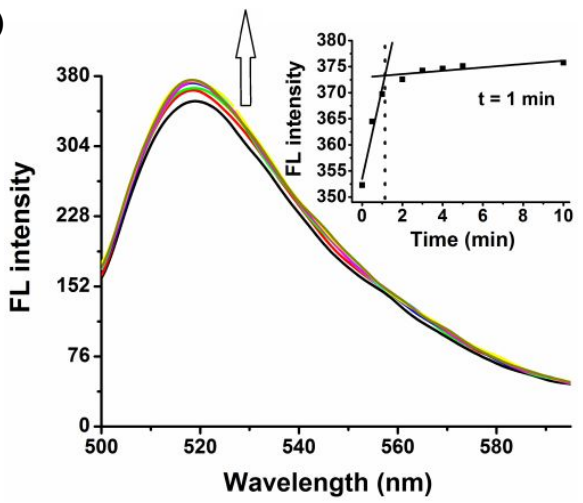

Figure S7. Fluorescence intensity of the P-DNA-1@Ru 1 system $(50 \mathrm{nM} / 5.0 \mu \mathrm{M})$ (a) and P-DNA-2@Ru 1 system $(50 \mathrm{nM} / 3.5 \mu \mathrm{M})$ (b) in the presence of target $\mathrm{T}_{1}$ or $\mathrm{T}_{2}(10 \mathrm{nM})$ at varying incubation time. Insets: plots of fluorescence intensity at $608 \mathrm{~nm}$ and $518 \mathrm{~nm}$ versus the incubation time for $\mathrm{T}_{1}$ (a) or $\mathrm{T}_{2}(\mathrm{~b})$.

(a)

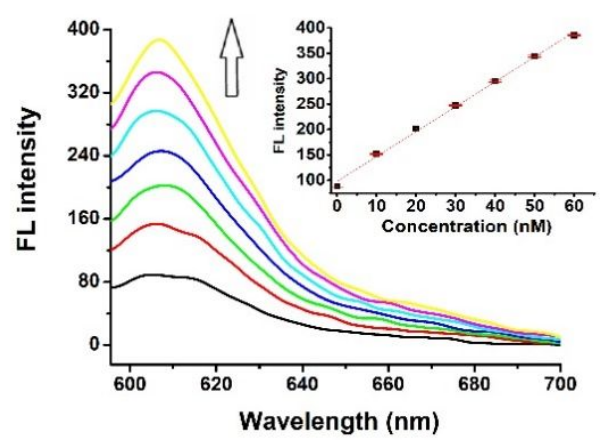

(b)

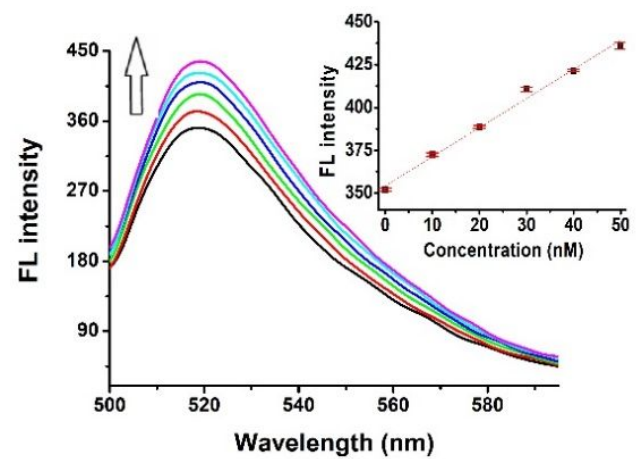

Figure S8. Fluorescence spectra of the P-DNA-1@Ru 1 system $(50 \mathrm{nM} / 5.0 \mu \mathrm{M})$ (a) and P-DNA-2@Ru 1 system (50 nM/3.5 $\mu \mathrm{M})$ (b) incubated with $\mathrm{T}_{1}$ or $\mathrm{T}_{2}$ of varying concentrations at room temperature. Inset: plot of the fluorescence intensity at $608 \mathrm{~nm}$ and $518 \mathrm{~nm}$ versus the concentrations of $T_{1}$ or $T_{2}(a, 0 \sim 60 \mathrm{nM} ; b, 0 \sim 50 \mathrm{nM})$.

(a)

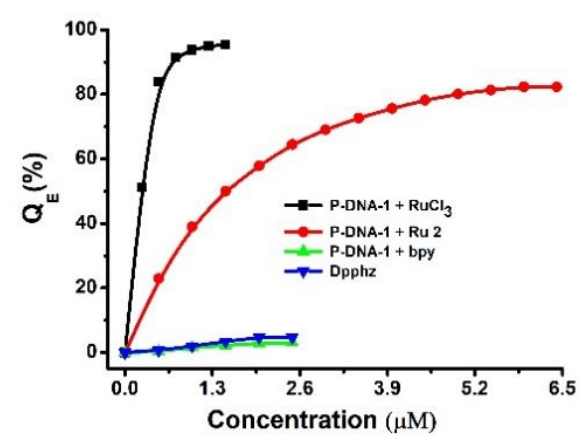

(b)

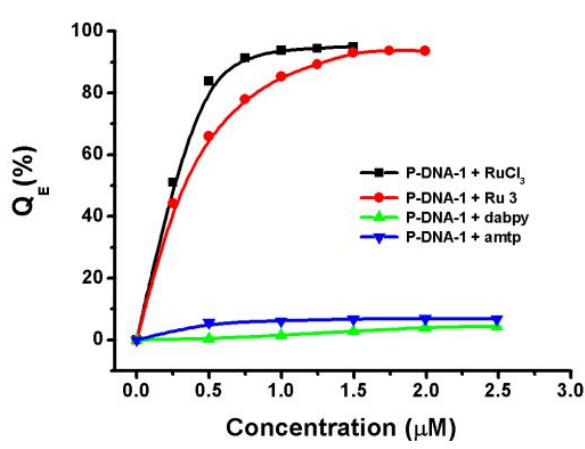


(c)

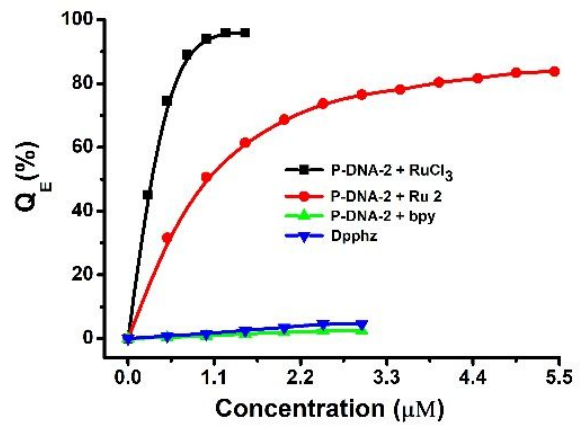

(d)

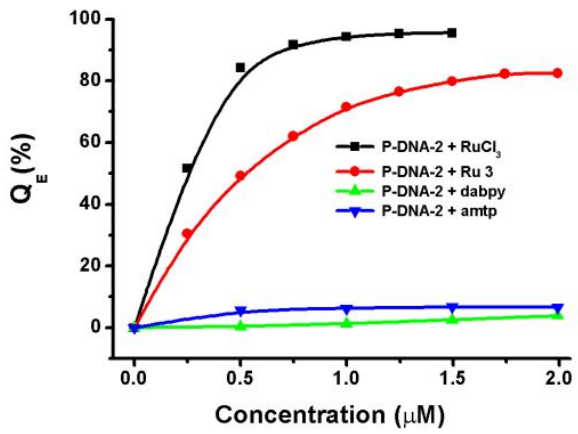

Figure S9. Fluorescence quenching efficiency $\left(\mathrm{Q}_{\mathrm{E}}\right)$ of P-DNA-1 $(50 \mathrm{nM})$ by $\mathbf{R u} \mathbf{2}, \mathrm{RuCl}_{3}$, bpy, Dpphz (a); Ru 3, $\mathrm{RuCl}_{3}$, dabpy, amtp (b) and P-DNA-2 (50 nM) by Ru 2, $\mathrm{RuCl}_{3}$, bpy, Dpphz (c); Ru 3, $\mathrm{RuCl}_{3}$, dabpy, amtp (d) of varying concentrations in $100 \mu \mathrm{M}$ Tris-HCl buffer (pH 7.4) at room temperature.

(a)

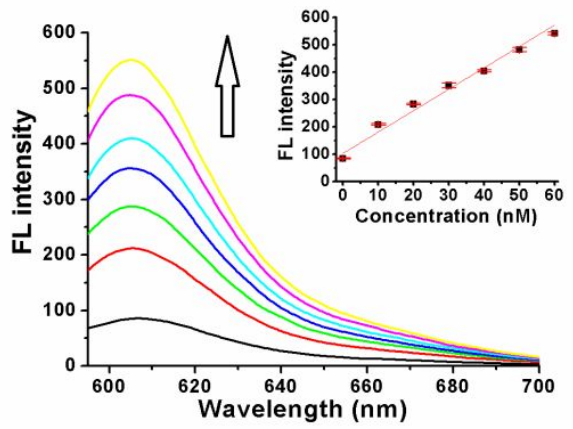

(c)

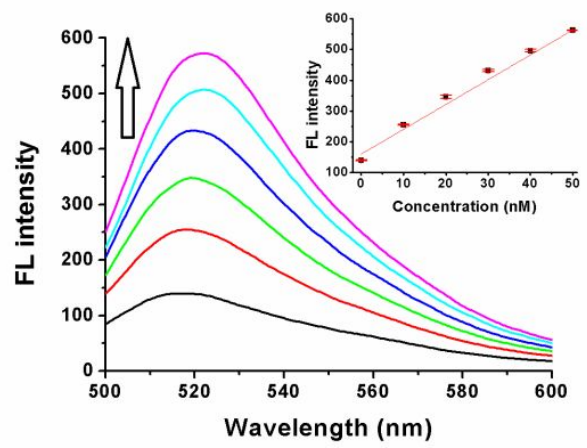

(e)

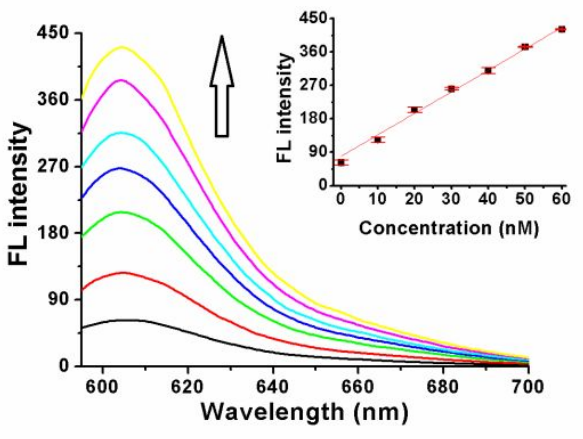

(b)

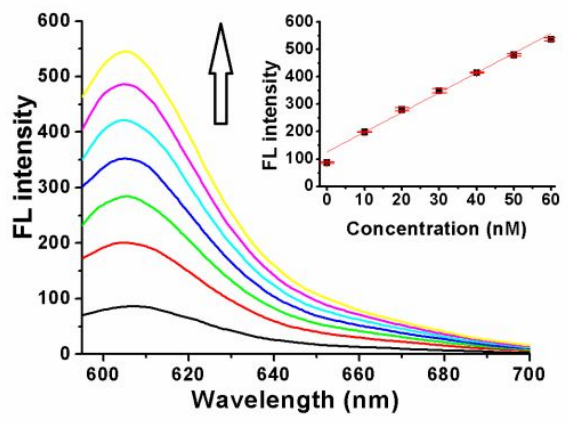

(d)

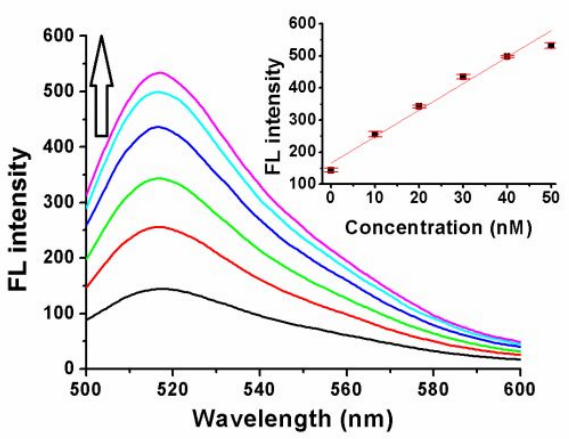

(f)

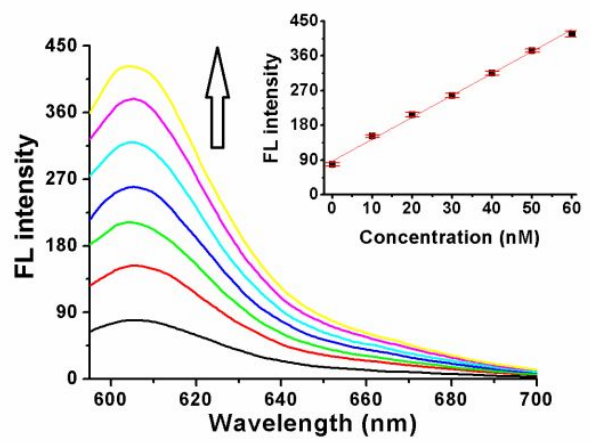

11 
$(\mathrm{g})$

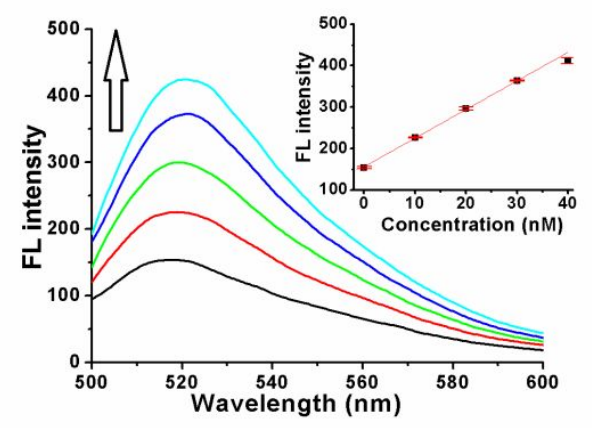

(h)

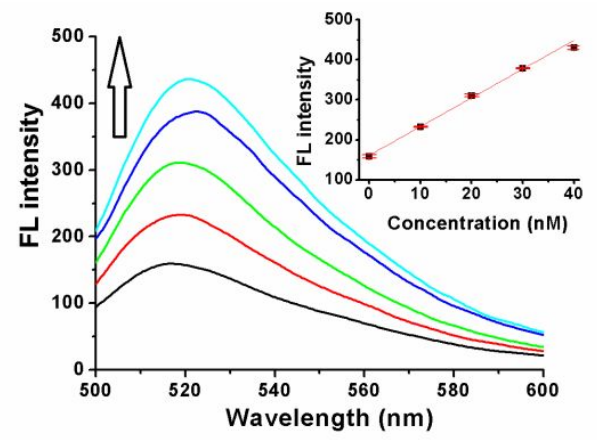

Figure S10. Fluorescence spectra of the P-DNA-1@Ru 2 system $(50$ nM/3.5 $\mu \mathrm{M})(\mathrm{a}-\mathrm{b})$, P-DNA-1@Ru 3 system $(50$ nM/2.0 $\mu \mathrm{M})$ (c-d), P-DNA-2@Ru 2 system $(50 \mathrm{nM} / 4.0 \mu \mathrm{M})$ (e-f) and P-DNA-2@Ru 3 system $(50 \mathrm{nM} / 1.5 \mu \mathrm{M})(\mathrm{g}-\mathrm{h})$ incubated with $\mathrm{T}_{1}$ (a-d) or $\mathrm{T}_{2}$ (e-h) of varying concentrations after different times $(12 \mathrm{~h} / 24 \mathrm{~h})(\mathrm{a}, \mathrm{c}, \mathrm{e}, \mathrm{g} / \mathrm{b}, \mathrm{d}, \mathrm{f}, \mathrm{h})$ at room temperature. Inset: plot of the fluorescence intensity at $608 \mathrm{~nm}$ and $518 \mathrm{~nm}$ versus the concentrations of $\mathrm{T}_{1}$ or $\mathrm{T}_{2}$ (a-d, $0 \sim$ $60 \mathrm{nM}$; e-f, $0 \sim 50 \mathrm{nM}$; g-h, $0 \sim 40 \mathrm{nM})$.
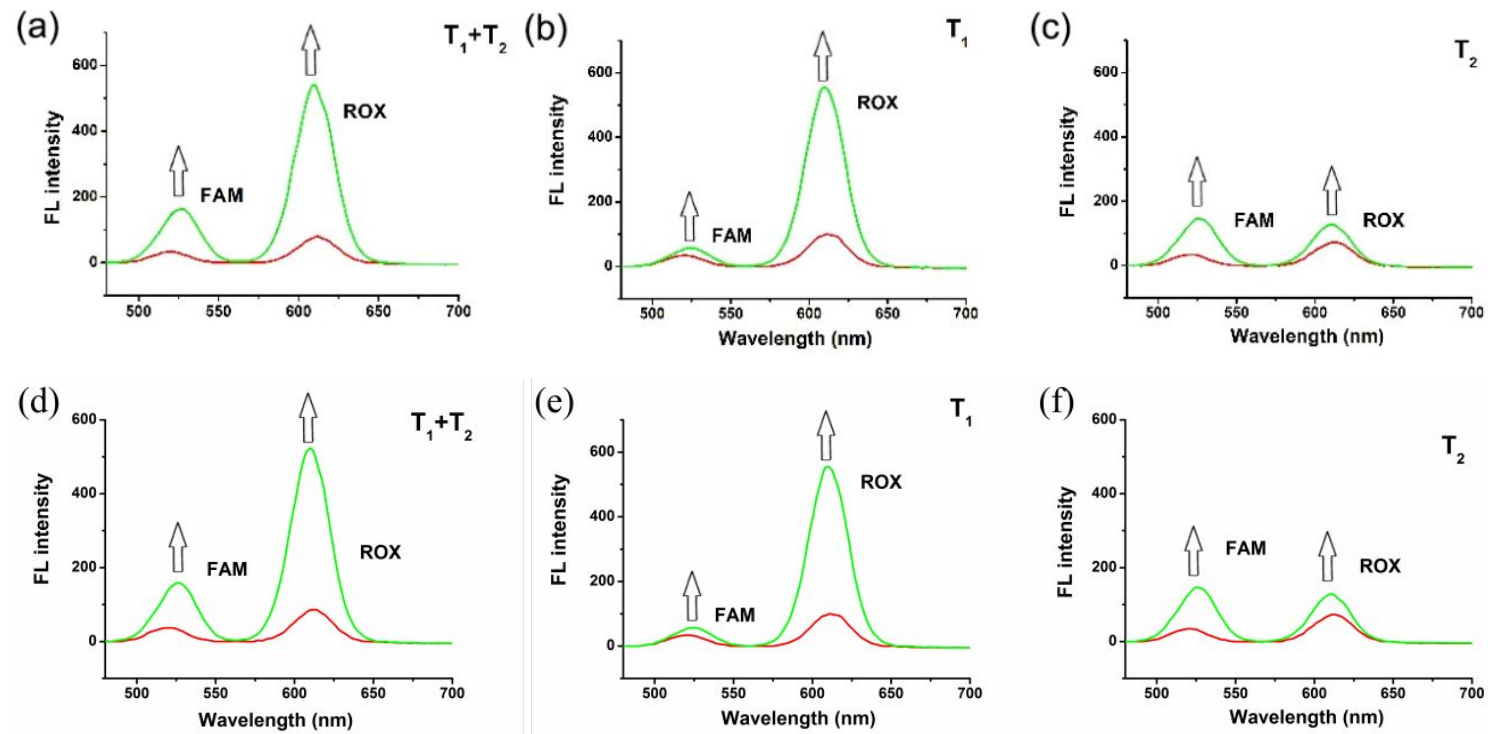

Figure S11. Sensing selectivity and specificity experiments: the fluorescence spectra of P-DNAs@Ru 2 with $T_{1}$ and $T_{2}(a), T_{1}$ (b) $T_{2}$ (c). The fluorescence spectra of P-DNAs@Ru 3 with $\mathrm{T}_{1}$ and $\mathrm{T}_{2}(\mathrm{~d}), \mathrm{T}_{1}$ (e) and $\mathrm{T}_{2}$ (f). ( $\mathrm{T}_{1}$ and $\mathrm{T}_{2}: 100 \mathrm{nM}$; P-DNAs@Ru 2: $50 \mathrm{nM} / 6.0 \mu \mathrm{M}$; P-DNAs@Ru 3: $50 \mathrm{nM} / 3.0 \mu \mathrm{M})$. 
(a)

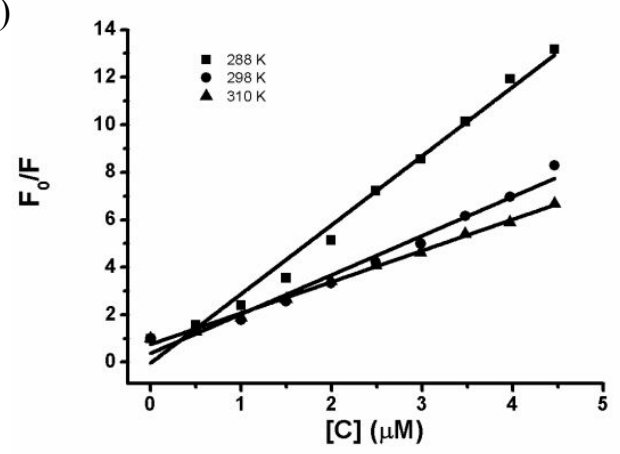

(c)

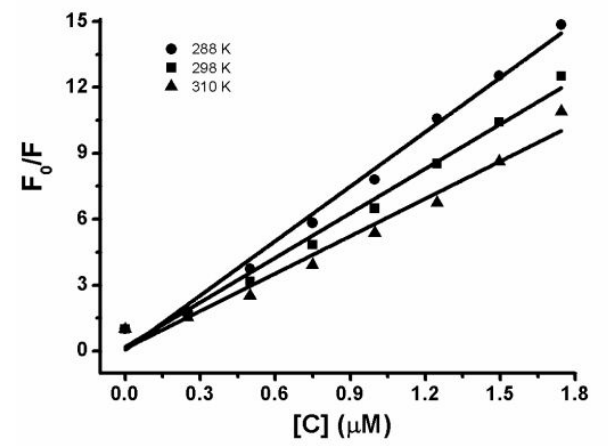

(e)

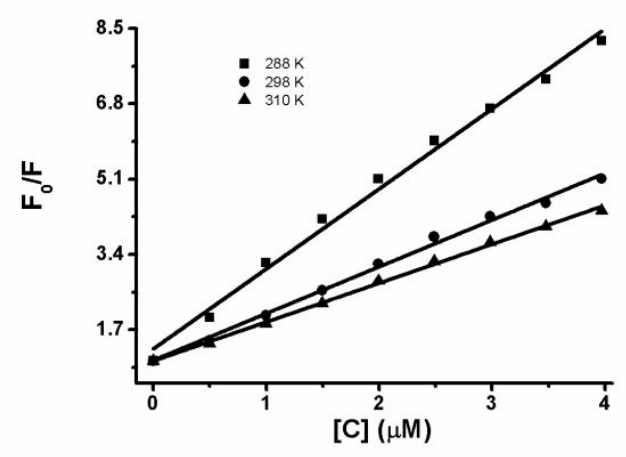

(b)

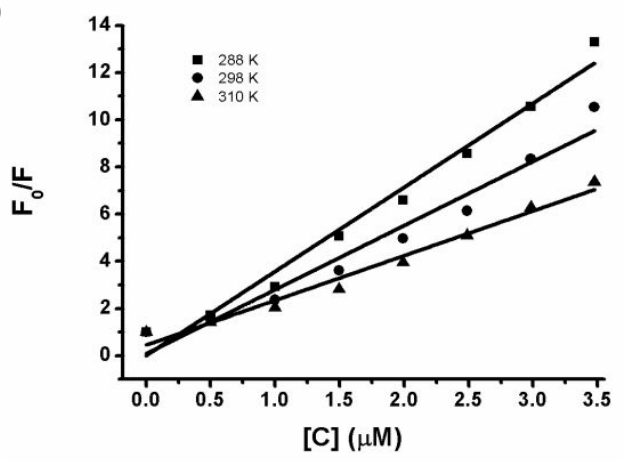

(d)

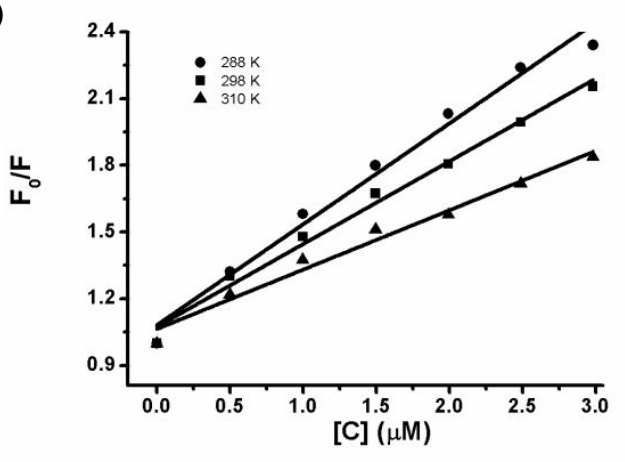

Figure S12. The Stern-Volmer plots for the fluorescence quenching of P-DNA-1 to Ru 1 (a); Ru 2 (b); Ru 3 (c) and P-DNA-2 to Ru 1 (d); Ru 2 (e) at different temperatures.

(a)

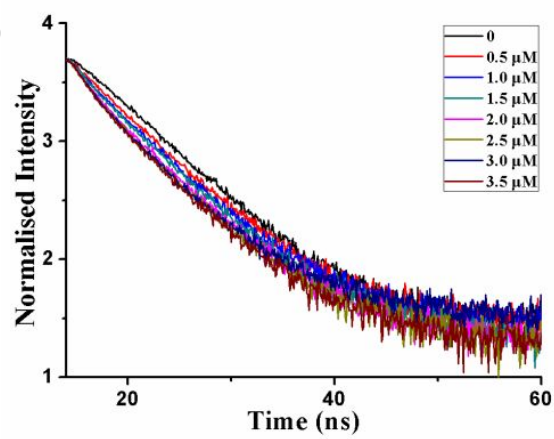

(b)

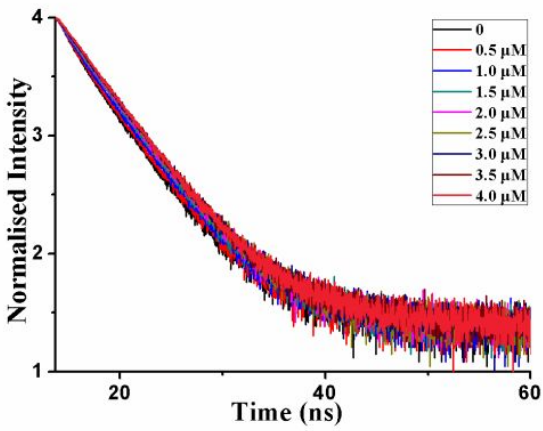

Figure S13. Semilog plots of fluorescence decay versus time of P-DNA-1 (50 nM, a, excited at 570 
$\mathrm{nm}$ and monitored at $608 \mathrm{~nm}$, respectively) and P-DNA-2 (50 nM, b, excited at $455 \mathrm{~nm}$ and monitored at $518 \mathrm{~nm}$, respectively) dispersed in Tris- $\mathrm{HCl}$ solution with the equilibrium concentration of Ru 2.

(a)

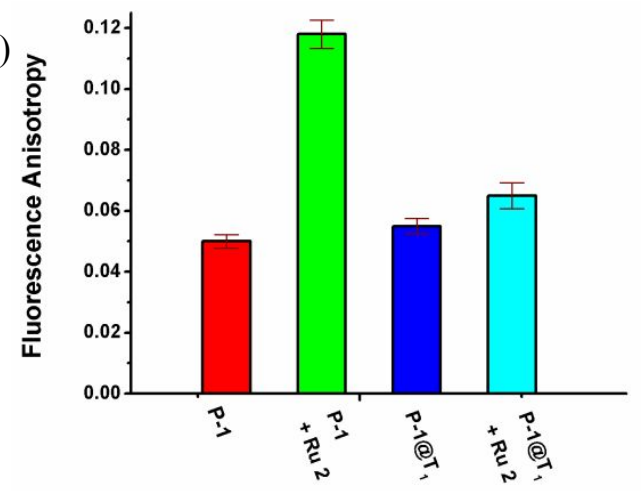

(c)

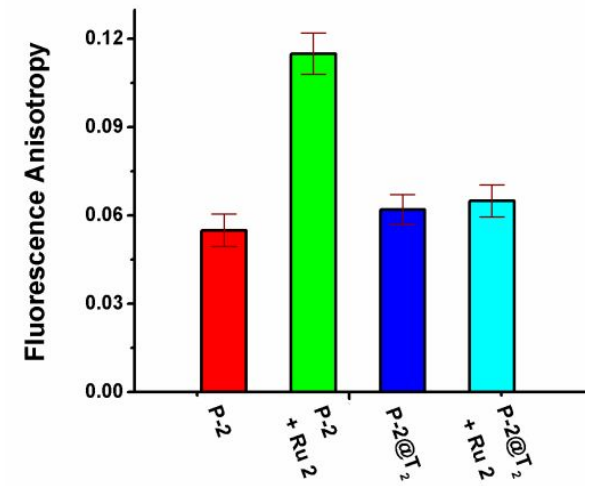

(b)

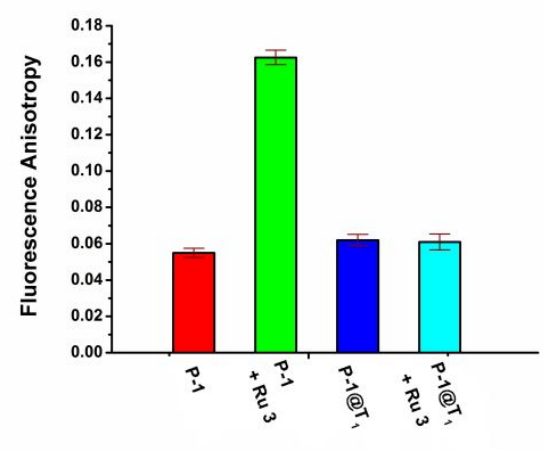

Figure S14. Fluorescence anisotropy changes of P-DNA-1 (P-1, $50 \mathrm{nM})$ or P-DNA-2 (P-2, 50 nM), P-1@ $\mathrm{T}_{1}$ or P-2@ $\mathrm{T}_{2}(50 \mathrm{nM} / 50 \mathrm{nM})$ before and after the addition of Ru (II) complexes (a, $5.0 \mu \mathrm{M}$ for Ru 2; b, $2.0 \mu \mathrm{M}$ for Ru 3; c, $3.5 \mu \mathrm{M}$ for Ru 2). The incubation time was 1 min for Ru 2 and 2 min for Ru 3, respectively.

(a)

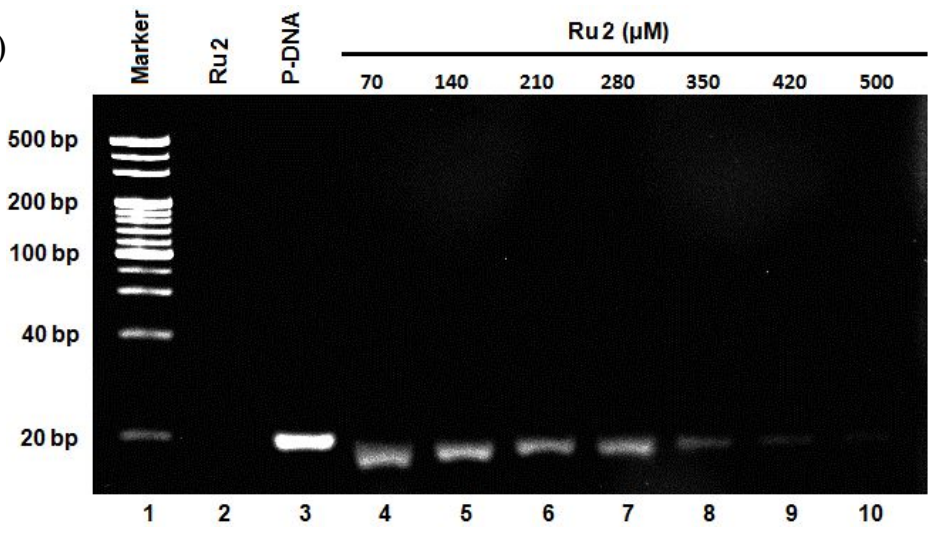




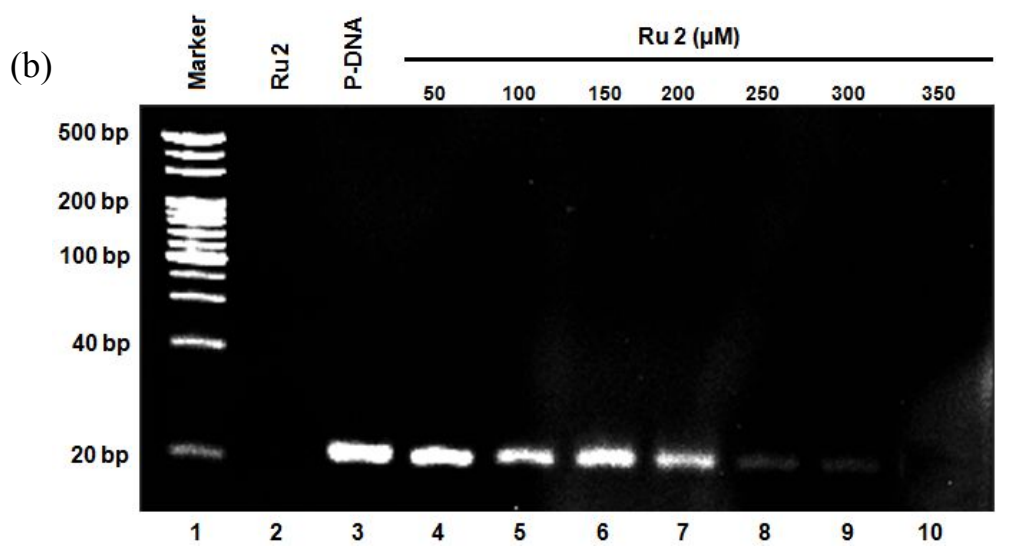

Figure S15. The concentration gradient experiments of PAGE, lane 1: marker; lane 2: Ru 2; lane 3: P-DNA(5 $\mu \mathrm{M})$; lane 4-10: different concentrations of the Ru $2(50 \mu \mathrm{M}, 100 \mu \mathrm{M}, 150 \mu \mathrm{M}, 200 \mu \mathrm{M}$, $250 \mu \mathrm{M}, 300 \mu \mathrm{M}$ and $350 \mu \mathrm{M})$ against P-DNA-1 $(5 \mu \mathrm{M}$, a) and P-DNA-2(5 $\mu \mathrm{M}, \mathrm{b})$

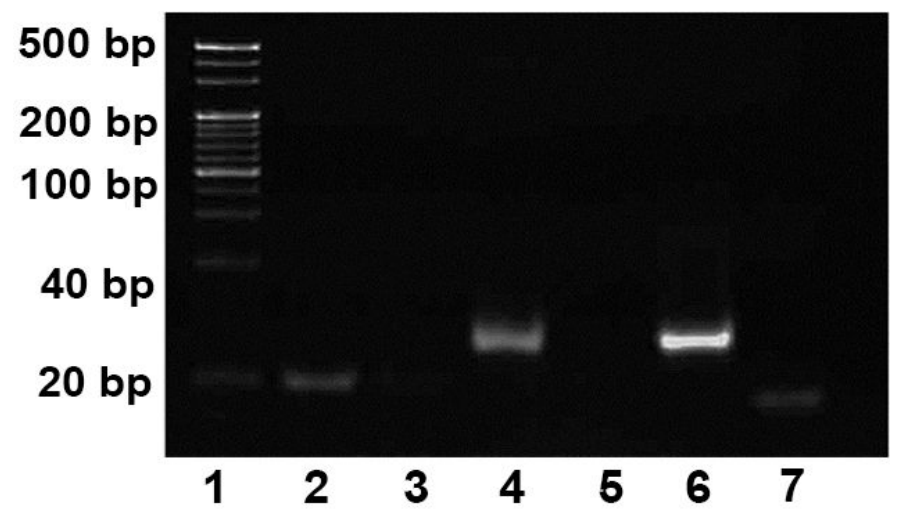

Figure S16. PAGE pattern of the P-DNA-2, $\mathrm{T}_{2}$, and their binding mixtures with the Ru 2, Lane 1: marker; lane 2: P-DNA-2; lane 3: P-DNA-2@Ru 2; lane 4: P-DNA-2@ $\mathrm{T}_{2}+$ Ru 2; lane 5: Ru 2; lane 6: P-DNA-2@ $\mathrm{T}_{2}$; lane 7: $\mathrm{T}_{2}$.

(a)

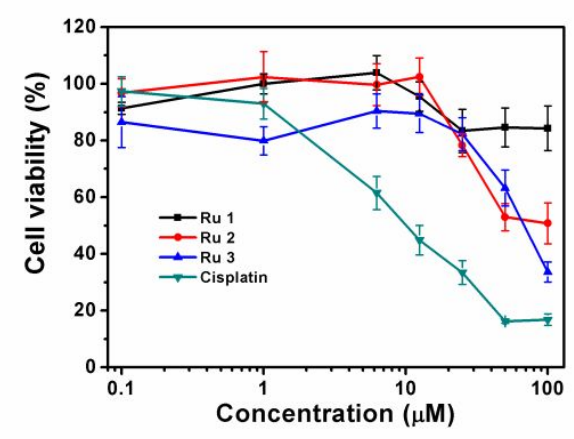

(b)

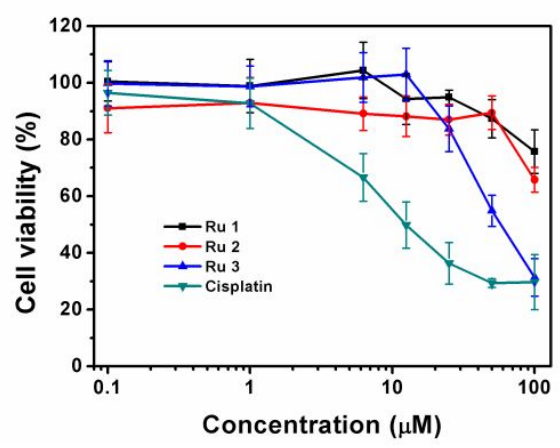

Figure S17. Cell viability of MDA-MB-231 (a) and MCF10A (b) cells in vitro treatment with Ru 1, Ru 2, Ru 3 and Cisplatin. Each data point is the mean \pm standard error obtained from at least three independent experiments. 


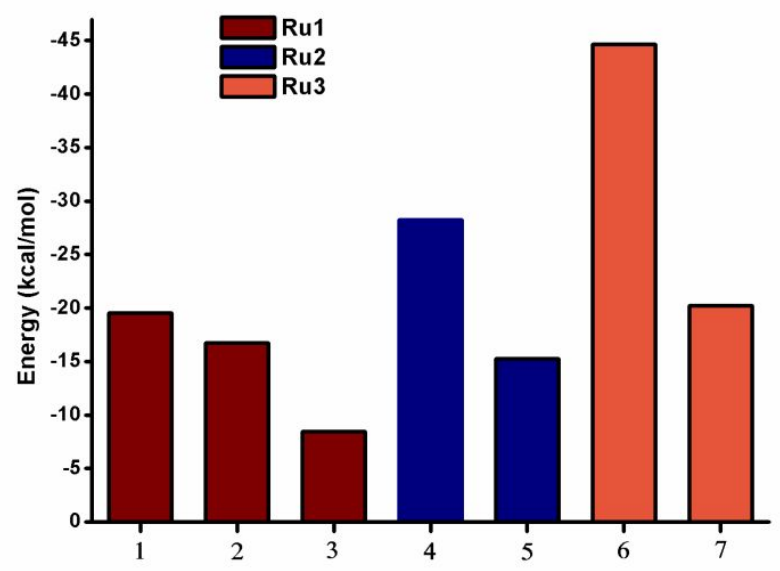

Figure S18. 1 represents the single point energies difference $(\Delta \Delta \mathrm{G})$ of $\Delta \mathrm{G}_{\text {P-DNA@Ru } 1 \text { with }}$ $\Delta \mathrm{G}_{\text {P-DNA@T185+Ru } 1}, 2$ represents $\Delta \Delta \mathrm{G}$ of $\Delta \mathrm{G}_{\text {P-DNA-1@Ru } 1}$ with $\Delta \mathrm{G}_{\text {P-DNA-1@T1+Ru } 1}, 3$ represents $\Delta \Delta \mathrm{G}$ of $\Delta \mathrm{G}_{\text {P-DNA-2@Ru } 1}$ with $\Delta \mathrm{G}_{\text {P-DNA-2@T2+Ru } 1}, 4$ represents $\Delta \Delta \mathrm{G}$ of $\Delta \mathrm{G}_{\text {P-DNA-1@Ru } 2}$ with $\Delta \mathrm{G}_{\text {P-DNA-1@T1+Ru } 2}$, 5 represents $\Delta \Delta \mathrm{G}$ of $\Delta \mathrm{G}_{\text {P-DNA-2@Ru } 2}$ with $\Delta \mathrm{G}_{\text {P-DNA-2@T2+Ru } 2}, 6$ represents $\Delta \Delta \mathrm{G}$ of $\Delta \mathrm{G}_{\text {P-DNA-1@Ru } 3}$ with $\Delta \mathrm{G}_{\mathrm{P}-\mathrm{DNA}-1 @ \mathrm{~T} 1+\mathrm{Ru} 3}, 7$ represents $\Delta \Delta \mathrm{G}$ of $\Delta \mathrm{G}_{\mathrm{P}-\mathrm{DNA}-2 @ \mathrm{Ru} 3}$ with $\Delta \mathrm{G}_{\mathrm{P}-\mathrm{DNA}-2 @ T 2+\mathrm{Ru} 3}$.

Table S1. $\Delta \Delta \mathrm{G}$ of $\Delta \mathrm{G}_{\mathrm{P}-\mathrm{DNA} 185 @ \mathrm{Ru} 1}$ with $\Delta \mathrm{G}_{\mathrm{P}-\mathrm{DNA} 185 @ T 185+\mathrm{Ru} 1}$. The single point energy $(\mathrm{G})$ results of P-DNA 185, P-DNA $185 @ \mathrm{~T}_{185}$, P-DNA $185 @ \mathbf{R u} 1$ and P-DNA $185 @ \mathrm{~T}_{185}+\mathbf{R u} \mathbf{1}$ are presented as the mean \pm s.d. of three measurements.

\begin{tabular}{|c|c|c|}
\hline System & Energy (Hartree) & Energy (kcal/mol) \\
\hline $\mathrm{G}_{\text {P-DNA185@Ru } 1}$ & $3.616 \pm 0.0347$ & $2261.831 \pm 24.374$ \\
\hline GP-DNA185@T185+Ru 1 & $7.668 \pm 0.0490$ & $4811.751 \pm 30.785$ \\
\hline $\mathrm{G}_{\mathrm{P}-\mathrm{DNA} 185}$ & $3.528 \pm 0.0187$ & $2214.141 \pm 11.761$ \\
\hline $\mathrm{G}_{\text {P-DNA185@T185 }}$ & $7.552 \pm 0.0495$ & $4738.952 \pm 31.087$ \\
\hline$\Delta \Delta G_{\text {average }}$ & -0.0311 & -19.504 \\
\hline
\end{tabular}

Table S2. $\Delta \Delta \mathrm{G}$ of $\Delta \mathrm{G}_{\text {P-DNA-1@Ru } 1}$ with $\Delta \mathrm{G}_{\mathrm{P}-\mathrm{DNA} A-1 @ T 1+\text { Ru } 1}$. The single point energy (G) results of P-DNA-1, P-DNA-1@T, P-DNA-1@Ru 1 and P-DNA-1@ $\mathrm{T}_{1}+\mathbf{R u} 1$ are presented as the mean \pm s.d. of three measurements.

\begin{tabular}{ccc}
\hline System & Energy (Hartree) & Energy (kcal/mol) \\
\hline $\mathrm{G}_{\text {P-DNA-1@Ru 1 }}$ & $4.153 \pm 0.0138$ & $2605.957 \pm 8.661$ \\
$\mathrm{G}_{\text {P-DNA-1@T1+Ru 1 }}$ & $8.100 \pm 0.0339$ & $5082.528 \pm 21.272$ \\
$\mathrm{G}_{\text {P-DNA-1 }}$ & $4.035 \pm 0.0156$ & $2531.685 \pm 9.807$ \\
$\mathrm{G}_{\text {P-DNA-1@T1 }}$ & $7.954 \pm 0.00874$ & $4991.525 \pm 5.501$ \\
$\boldsymbol{\Delta} \boldsymbol{\Delta} \mathbf{G}_{\text {average }}$ & $\mathbf{- 0 . 0 2 6 7}$ & $\mathbf{- 1 6 . 7 3 0}$ \\
\hline
\end{tabular}


Table S3. $\Delta \Delta \mathrm{G}$ of $\Delta \mathrm{G}_{\mathrm{P}-\mathrm{DNA}-2 @ \mathrm{Ru} 1}$ with $\Delta \mathrm{G}_{\mathrm{P}-\mathrm{DNA}-2 @ \mathrm{~T} 2+\text { Ru 1 }}$. The single point energy $(\mathrm{G})$ results of P-DNA-2, P-DNA-2@T $\mathrm{T}_{2}, \mathrm{P}-\mathrm{DNA}-2 @ \mathbf{R u} 1$ and P-DNA-2@ $\mathrm{T}_{2}+\mathbf{R u} 1$ are presented as the mean \pm s.d. of three measurements.

\begin{tabular}{ccc}
\hline System & Energy (Hartree) & Energy (kcal/mol) \\
\hline $\mathrm{G}_{\mathrm{P}-\mathrm{DNA}-2 @ \text { Ru 1 }}$ & $3.748 \pm 0.0367$ & $2352.080 \pm 23.004$ \\
$\mathrm{G}_{\text {P-DNA-2@T2+Ru 1 }}$ & $7.310 \pm 0.0127$ & $4587.318 \pm 7.985$ \\
$\mathrm{G}_{\mathrm{P}-\mathrm{DNA}-2}$ & $3.605 \pm 0.0449$ & $2261.977 \pm 28.211$ \\
$\mathrm{G}_{\text {P-DNA-2@T2 }}$ & $7.153 \pm 0.00691$ & $4488.765 \pm 4.350$ \\
$\boldsymbol{\Delta} \boldsymbol{\Delta} \mathbf{G}_{\text {average }}$ & $\mathbf{- 0 . 0 1 3 5}$ & $\mathbf{- 8 . 4 4 8}$ \\
\hline
\end{tabular}

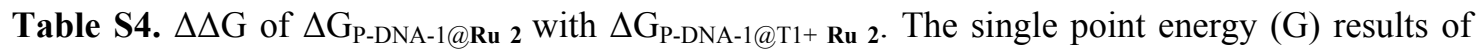
P-DNA-1, P-DNA@T 1 , P-DNA-1@Ru 2 and P-DNA-1@ $\mathrm{T}_{1}+\mathbf{R u} 2$ are presented as the mean \pm s.d. of three measurements.

\begin{tabular}{ccc}
\hline System & Energy (Hartree) & Energy $(\mathbf{k c a l} / \mathbf{m o l})$ \\
\hline $\mathrm{G}_{\text {P-DNA-1@Ru 2 }}$ & $4.578 \pm 0.0258$ & $2872.796 \pm 16.208$ \\
$\mathrm{G}_{\text {P-DNA-1@T1+Ru 2 }}$ & $8.811 \pm 0.101$ & $5528.891 \pm 63.339$ \\
$\mathrm{G}_{\text {P-DNA-1 }}$ & $4.462 \pm 0.0100$ & $2800.178 \pm 6.294$ \\
$\mathrm{G}_{\text {P-DNA-1@T1 }}$ & $8.650 \pm 0.0798$ & $5428.045 \pm 50.097$ \\
$\boldsymbol{\Delta} \mathbf{\Delta} \mathbf{G}_{\text {average }}$ & $\mathbf{- 0 . 0 4 5 0}$ & $\mathbf{- 2 8 . 2 2 8}$ \\
\hline
\end{tabular}

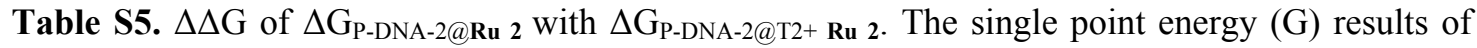
P-DNA-2, P-DNA-2@, T, P-DNA-2@Ru 2 and P-DNA-2@ $\mathrm{T}_{2}+\mathbf{R u} 2$ are presented as the mean \pm s.d. of three measurements.

\begin{tabular}{ccc}
\hline System & Energy (Hartree) & Energy (kcal/mol) \\
\hline $\mathrm{G}_{\text {P-DNA-2@Ru 2 }}$ & $4.106 \pm 0.0272$ & $2576.669 \pm 17.041$ \\
$\mathrm{G}_{\text {P-DNA-2@T2+Ru 2 }}$ & $7.956 \pm 0.0157$ & $4992.767 \pm 9.837$ \\
$\mathrm{G}_{\text {P-DNA-2 }}$ & $3.959 \pm 0.0334$ & $2484.524 \pm 20.967$ \\
$\mathrm{G}_{\text {P-DNA-2@T2 }}$ & $7.789 \pm 0.00589$ & $4885.385 \pm 3.703$ \\
$\boldsymbol{\Delta} \boldsymbol{\Delta} \mathbf{G}_{\text {average }}$ & $\mathbf{- 0 . 0 2 4 3}$ & $\mathbf{- 1 5 . 2 3 7}$ \\
\hline
\end{tabular}

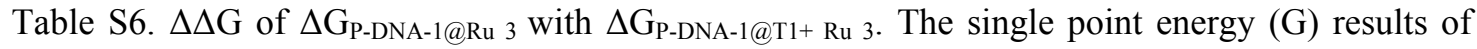
P-DNA-1, P-DNA-1@ $\mathrm{T}_{1}, \mathrm{P}-\mathrm{DNA}-1 @ \mathrm{Ru} 3$ and P-DNA-1@ $\mathrm{T}_{1}+\mathrm{Ru} 3$ are presented as the mean \pm s.d. of three measurements.

\begin{tabular}{ccc}
\hline System & Energy (Hartree) & Energy (kcal/mol) \\
\hline G $_{\text {P-DNA-1@Ru 3 }}$ & $4.533 \pm 0.0285$ & $2844.583 \pm 17.856$
\end{tabular}




\begin{tabular}{ccc}
$\mathrm{G}_{\mathrm{P}-\mathrm{DNA}-1 @ \mathrm{~T} 1+\mathrm{Ru} 3}$ & $8.750 \pm 0.0373$ & $5490.903 \pm 23.433$ \\
$\mathrm{G}_{\mathrm{P}-\mathrm{DNA}-1}$ & $4.468 \pm 0.0177$ & $2803.998 \pm 11.089$ \\
$\mathrm{G}_{\text {P-DNA-1@T1 }}$ & $8.615 \pm 0.0311$ & $5405.662 \pm 19.533$ \\
$\boldsymbol{\Delta} \boldsymbol{\Delta} \mathbf{G}_{\text {average }}$ & $\mathbf{- 0 . 0 7 1 2}$ & $\mathbf{- 4 4 . 6 5 4}$ \\
\hline
\end{tabular}

Table S7. $\Delta \Delta \mathrm{G}$ of $\Delta \mathrm{G}_{\mathrm{P}-\mathrm{DNA}-2 @ \mathrm{Ru} 3}$ with $\Delta \mathrm{G}_{\mathrm{P}-\mathrm{DNA}-2 @ \mathrm{~T} 2+\mathrm{Ru} 3}$. The single point energy $(\mathrm{G})$ results of P-DNA-2, P-DNA-2@T $\mathrm{T}_{2}, \mathrm{P}-\mathrm{DNA}-2 @ \mathbf{R u} 3$ and P-DNA-2@ $\mathrm{T}_{2}+\mathbf{R u} 3$ are presented as the mean \pm s.d. of three measurements.

\begin{tabular}{ccc}
\hline System & Energy (Hartree) & Energy (kcal/mol) \\
\hline $\mathrm{G}_{\mathrm{P}-\mathrm{DNA}-2 @ \text { Ru 3 }}$ & $4.082 \pm 0.0284$ & $2561.732 \pm 17.814$ \\
$\mathrm{G}_{\mathrm{P}-\mathrm{DNA}-2 @ \mathrm{~T} 2+\mathrm{Ru} 3}$ & $7.959 \pm 0.0301$ & $4994.550 \pm 18.887$ \\
$\mathrm{G}_{\mathrm{P}-\mathrm{DNA}-2}$ & $3.973 \pm 0.0223$ & $2493.143 \pm 13.997$ \\
$\mathrm{G}_{\text {P-DNA-2@T2 }}$ & $7.818 \pm 0.0174$ & $4905.744 \pm 10.919$ \\
$\boldsymbol{\Delta} \mathbf{\Delta} \mathbf{G}_{\text {average }}$ & $\mathbf{- 0 . 0 3 2 2}$ & $\mathbf{- 2 0 . 2 1 7}$ \\
\hline
\end{tabular}

Table S8. The detection efficiency and selectivity data for P-DNA+ Ru or P-DNA@Ru systems by single fluorescence analysis.

\begin{tabular}{|c|c|c|c|c|c|c|c|c|c|}
\hline $\mathrm{P}-\mathrm{DNA}+\mathrm{Ru}$ & $\begin{array}{l}\mathrm{Q}_{\mathrm{E}} \\
(\%)\end{array}$ & $\Delta \mathrm{F}_{1}$ & {$[\mathrm{C}]$} & $\begin{array}{c}\text { P-DNA@ } \\
\mathrm{Ru}\end{array}$ & $\begin{array}{l}\mathrm{R}_{\mathrm{E}} \\
\text { for } \\
\mathrm{T}_{1}\end{array}$ & $\Delta \mathrm{F}_{2}$ & $\begin{array}{c}R_{E} \\
\text { for } T_{2}\end{array}$ & Time & LOD \\
\hline P-DNA-1 + 1 & 89 & 724.9 & 5.0 & P-DNA-1@1 & 3.9 & 367.0 & l & 1 & 0.22 \\
\hline P-DNA-2 $+\mathbf{1}$ & 56 & 449.2 & 3.5 & P-DNA-2@1 & / & 104.9 & 0.3 & 1 & 0.72 \\
\hline P-DNA-1 $+\mathbf{2}$ & 91 & 757.8 & 3.5 & P-DNA-1@2 & 7.0 & 578.4 & l & 1 & 0.12 \\
\hline P-DNA-2 + 2 & 84 & 689.1 & 4.0 & P-DNA-2@2 & / & 403.1 & 3.1 & 1 & 0.10 \\
\hline P-DNA-1 +3 & 94 & 773.3 & 2.0 & P-DNA-1@3 & 7.7 & 402.5 & I & 1 & 0.16 \\
\hline P-DNA-2 +3 & 83 & 658.8 & 1.5 & P-DNA-2@3 & I & 310.7 & 2.3 & 2 & 0.14 \\
\hline
\end{tabular}

Note: Unit of the Time is min, LOD is $\mathrm{nM},[\mathrm{C}]$ (the quenching concentration of ruthenium complexes) is $\mu \mathrm{M} ; \Delta \mathrm{F}_{1}$ represents the difference of fluorescence intensity for quenching, $\Delta \mathrm{F}_{2}$ represents the difference of fluorescence intensity for recovering.

Table S9. The detection efficiency and selectivity data for P-DNA+Ru or P-DNA@Ru systems by synchronous fluorescence analysis.

\begin{tabular}{ccccccccc}
\hline & & & & P-DNAs & & Time & LOD \\
P-DNAs+Ru & $\mathrm{Q}_{\mathrm{E}}(\%)$ & $\Delta \mathrm{F}_{1}$ & {$[\mathrm{C}]$} & $\Delta \mathrm{F}_{2}$ & $\mathbf{R u}$ & $\mathrm{R}_{\mathrm{E}}$ & for & for \\
& & & & & & for $\mathrm{T}_{1} / \mathrm{T}_{2}$ & $\mathrm{~T}_{1} / \mathrm{T}_{2}$ & $\mathrm{~T}_{1} / \mathrm{T}_{2}$ \\
\hline P-DNAs+2 & $92 / 93$ & $840.3 / 460.0$ & $6.0 / 6.0$ & $461.8 / 113.2$ & P-DNAs@2 & $5.4 / 3.4$ & $1 / 1$ & $0.19 / 0.52$ \\
P-DNAs $+\mathbf{3}$ & $91 / 91$ & $893.6 / 387.3$ & $3.0 / 3.0$ & $423.4 / 96.8$ & P-DNAs@3 & $4.7 / 2.6$ & $2 / 2$ & $0.28 / 1.03$ \\
\hline
\end{tabular}


Note: Unit of the Time is min, LOD is $\mathrm{nM},[\mathrm{C}]$ (the quenching concentration of ruthenium complexes) is $\mu \mathrm{M} ; \Delta \mathrm{F}_{1}$ represents the difference of fluorescence intensity for quenching, $\Delta \mathrm{F}_{2}$ represents the difference of fluorescence intensity for recovering.

Table S10. The $K_{D}$ values of P-DNA-1/P-DNA-2 toward Ru 1, Ru 2 and Ru 3 at different temperatures.

\begin{tabular}{cccccccc}
\hline & \multicolumn{3}{c}{ P-DNA-1 $\left(\mathrm{K}_{\mathrm{D}} \times 10^{6} \mathrm{M}^{-1}\right)$} & & \multicolumn{3}{c}{ P-DNA-2 $\left(\mathrm{K}_{\mathrm{D}} \times 10^{6} \mathrm{M}^{-1}\right)$} \\
\cline { 2 - 3 } \cline { 6 - 8 } \cline { 6 - 8 } & $288 \mathrm{~K}$ & $298 \mathrm{~K}$ & $310 \mathrm{~K}$ & & $288 \mathrm{~K}$ & $298 \mathrm{~K}$ & $310 \mathrm{~K}$ \\
\hline Ru 1 & 1.91 & 1.50 & 1.25 & & 0.53 & 0.44 & 0.33 \\
Ru 2 & 2.57 & 1.82 & 1.35 & & 2.08 & 1.07 & 0.87 \\
Ru 3 & 7.31 & 6.04 & 4.82 & & 4.32 & 2.55 & 1.85 \\
\hline
\end{tabular}

Table S11. The $\mathrm{K}_{\mathrm{a}}$ and $\mathrm{n}$ values of P-DNA-1/ P-DNA-2 and duplexes P-DNA-1/ P-DNA-2@T with Ru 1, Ru 2 and Ru 3 at room temperature (293K).

\begin{tabular}{lllllllll}
\hline & \multicolumn{7}{c}{$\mathrm{K}_{\mathrm{a}} \times 10^{6} \mathrm{M}^{-1}$} \\
\cline { 2 - 8 } & P-DNA-1 & $\mathrm{n}$ & P-DNA-1@ $\mathrm{T}_{1}$ & $\mathrm{n}$ & P-DNA-2 & $\mathrm{n}$ & P-DNA-2@ $\mathrm{T}_{2}$ & $\mathrm{n}$ \\
\hline Ru 1 & 1.87 & 1.19 & 0.35 & 0.93 & 0.40 & 1.07 & 0.25 & 1.09 \\
Ru 2 & 3.21 & 1.20 & 0.46 & 0.88 & 1.21 & 1.14 & 0.31 & 0.93 \\
Ru 3 & 6.01 & 1.19 & 1.07 & 0.90 & 2.94 & 1.12 & 0.57 & 0.93 \\
\hline
\end{tabular}

